\section{Tomorrow's tasks}

\section{This week's new government must address itself urgently to the needs of its research enterprise.}

TODAY's election in Britain means that there will be a new government in office tomorrow, 12 June. Most probably, it will be a replica of Mrs Margaret Thatcher's administration of the past eight years, but with a smaller majority in the House of Commons. But even if the Labour Party, the largest of the opposition parties, has managed in the day or so before the counting of the ballots to redress the imbalance against it showing consistently in the opinion polls, the opportunities and the problems will be what they have been for the past several years. Britain retains its conviction that there must be some way of turning science into prosperity and is fiscally in better shape than for many years, but still has three million adults unemployed and has demoralized its research enterprise and its institutions of higher education. The pursuit of fiscal rectitude, entirely laudable, is why, since 1980 , public support for higher education and (with caveats) for basic research have both declined. The British, government and otherwise, have given little thought to the complementary question of whether the length of the dole queues is related to what has been done to British education.

That is the issue to which the new British government should bend its energies, and more radically than any party has been promising, for there is ample evidence that the dole queues are filled with people who would be at work if their education had been better suited to the world in which Britain aspires to live. The economic history of the past decade makes that plain. Traditional industries, from textiles to steel-making, have been in decline for the four decades since the Second World War for two reasons - traditional manufacturing did not allow a highwage economy to compete with manufacturers elsewhere, but there has been neither the capital investment nor the technical innovation that would have allowed profitable competition in the niches of the global markets that others have discovered. Two developments in the early 1970s accentuated Britain's economic problems; membership of the European Economic Community made the competition more effective, while the exploitation of North Sea oil, by increasing the value of the British currency relative to others, had the same effect. The result, as the opposition parties complained during the election, is that British manufacturing output has hardly changed since 1979. The real growth of the British economy since then consists largely of North Sea oil and of the service sector of the economy.

This thumbnail sketch is nowhere challenged. Controversy centres on two questions. How, first, to remedy this state of affairs by "creating" jobs? Opposition plans to spend money on the improvement of Britain's infrastructure would take many people off the dole, but more construction can be only a shortterm remedy, and could be inflationary as well. So why, more radically, has Britain not experienced the uprush of new manufacturing enterprises, making products that did not exist in the $1950 \mathrm{~s}$, which has marked the recent history of countries as different as Italy, South Korea, the United States and - spectacularly - Japan? Shortage of venture capital, once a drag, is no longer a difficulty. There has also been some notable if unobtrusive growth of the kind for which the British yearn - the pharmaceutical and chemical industries have grown on the back of technical innovation, as indeed has the electronics industry. The snag, and one cause of the Thatcher government's discontent, is that growth in manufacture of electronics has not been as spectacular as that of the world market, or of Britain's own consumption of electronic goods.

Why should this be? Eight years ago, the government's diagnosis was that the British economic climate was inimical to entrepreneurs, whence its policy of reducing taxes. Soon afterwards, the government seems to have come to its own interpretation of the legend that Britain is better at invention than exploitation, whence its twin policies of persuading research councils towards practical problems and of cutting the budgets of the universities to make them more economical and, latterly, to push them into the arms of industry. The logic is seductive, but the consequences are entirely unexpected. The research councils have been so harried by enforced reorganisation and the creeping shortage of funds that their programmes have taken on the appearence of exercises in public welfare. And the universities, once shielded from direct dialogue with the government by the University Grants Committee, now find themselves harried individually from the centre. The University of Aberdeen seems narrowly to be avoiding the prospect of bankruptcy by planning to shed 150 academics. University College Cardiff has been given until today, 11 June, to choose between bankruptcy and a forced merger with a smaller college on terms dictated by the latter. There seems to be little understanding of the effects of these upheavals on the morale of the people who work in the research institutes concerned, let alone of the social and economic function of basic research and higher education.

This is where tomorrow's government must start. The first need is to understand that higher education is a means of producing the skilled people of a kind whose shortage, in Britain, is the chief reason for the lack of successful industrial innovation. Sadly, although the annual output of British graduates is approaching 100,000 , there is ample evidence in the economic experience of the past few years that this considerable output does not meet the economic need. The government's explanation, from which the opposition parties do not dissent, is that higher education pays too little attention to industry as such. What about this other possibility, that it is altogether too eccentric that most British degree courses should last for only three years and should ride on a high-school system marked by such specialisation that most school-leavers know either about science, or about the wider world, but not about both? Can it make sense that Britain, bent on the emulation of its successful competitors, should decline to follow them in worrying about the quality of the education it provides for its young people?

\section{Change}

To be fair, the previous government had awakened to the need for change by planning for a core curriculum in the schools, while universities and polytechnics have fallen in with proposals for a broader education of school-leavers. Sadly, these changes will be slow to take effect and are, in any case, compromises. Their success has been further compromised by the battle between the high-school teachers and the previous government, exacerbated by the government's improvisation of plans for allowing independence for all schools during its campaign for reelection. Why not remove the canker from the centre of British education by cutting the link between high-school and higher education, letting the former concentrate on educating young people and giving the latter an extra year to educate young adults?

Tomorrow's government must also go back on some of the administrative decisions of the past few years and months. The notion that there will in future be contracts between universities (or even university departments) and a central money-bag called the Universities' (or Polytechnics') Funding Council for the provision of educational services, which is a recipe for making both kinds of institutions less creative, should be quickly abandoned. The new government must also give the research enterprise time to recover from the traumas of the past few years. More money is not required. Instead, there needs to be a respite from the rhetoric of the past few years, based on the assumption that the only worthwhile research is that directed to the improvement of industrial performance. That ministers leap to these conclusions is understandable, which is one reason why the new government should be guided by wiser counsels. Ministers would be more usefully employed in restoring the morale of a scientific community so injured by the past eight years that its capacity ever to recover is now in doubt. 